Volume 13 Part 4 December 2012

Japanese

Journal of

Political

Science

\title{
CAMBRIDGE
}

UNIVERSITY PRESS 


\section{Executive Editor}

Takashi Inoguchi University of Niigata Prefecture, Japan

\section{Editors}

Ikuo Kabashima Govenor, Kumamoto, Japan

Junko Kato University of Tokyo, Japan

Michio Muramatsu Gakushiun University, Japan

Hideo Otake Doshisha Women's University, Japan

Steven R. Reed Chuo University/University of Tokyo, Japan

\section{Associate Editors}

Gary Cox University of California, San Diego, USA

Peter Hall Harvard University, USA

David Held London School of Economics, UK

Peter Katzenstein Cornell University, USA

Michael Laver New York University, USA

\section{International Advisory Board}

Suzanne Berger M.I.T., USA

Jean Blondel European University Institute, Italy

Hernando de Soto Institute of Liberty and Democracy,

Lima, Peru

Samuel Huntington Harvard University, USA

Max Kaase International University, Bremen

Ali Mazrui State University of New York, Binghamton, USA

Robert Putnam Harvard University, USA

Lucian W. Pye M.I.T., USA

Amartya Sen University of Cambridge, UK

J.A. A. Stockwin University of Oxford, UK

Sidney Verba Harvard University, USA

Wang Gungwu National University of Singapore
For Notes for Contributors please see inside back cover.

The Japanese Journal of Political Science welcomes contributions in all fields of the discipline, especially where these have a conceptual thrust, including political theory, comparative politics, political behaviour, political institutions, public policy, and international relations. At the same time, the journal seeks to attract the best comparative articles featuring Japan or East Asia. Each issue will contain full-length research articles, review articles, and book reviews.

Rigorously refereed to the highest scholarly standards, the key features of the journal include five or six full-length research articles in every issue; Letters to the Editor, providing a forum for comments and replies; regular reports covering executive turnovers, legislative enactment, elections and opinion polls; and book reviews in each issue.

\section{Internet access}

This journal is included in the Cambridge Journals Online service, which can be found at http://www.journals.cambridge.org. For further information on other Press titles access http://www.cambridge.org.

\section{Subscriptions}

The Japanese Journal of Political Science (issn 1468-1099, electronic 1474-0060) is published four times a year in March, June, September and December. Three parts form a volume.

The 2012 subscription price (excluding VAT) of a volume for institutional subscribers, which includes print and electronic access is $£ 178$ net (US\$295, in the USA, Canada and Mexico). The electronic only price available to institutional subscribers is $\mathfrak{E} 150 / \$ 248$. The price to individuals ordering direct from the publisher and certifying that the journal is for their personal use

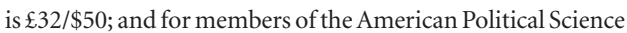
Association, Political Studies Association, International Studies Association, British International Studies Association, and Japanese Political Science Association, the print-only price is $£ 24 / \$ 36$. EU subscribers outside the UK who are not registered for VAT should add VAT at their country's rate. VAT registered subscribers should provide their VAT registration number. Orders must be accompanied by payment.
Orders with payment in pounds sterling may be sent to a bookseller, subscription agent, or to the publisher: Journals Customer Services, Cambridge University Press, FREEPOST ${ }^{*}$, The Edinburgh Building, Shaftesbury Road, Cambridge св2 8RU, UK

* No stamp necessary if posted within the UK.

TEL $+44(0) 1223-32-6070$

FAX $+44(0) 1223-31-5052$

E-MAIL journals_subscriptions@cup.cam.ac.uk WEB http://www.cambridge.org

Orders in the USA, Canada and Mexico, with payment in US or Canadian dollars, should be sent to: Cambridge University Press, Journals Fulfillment Department, 100 Brook Hill Drive, West Nyack, New York 10994-2133.

Orders may be phoned in direct, toll free, on 1-800-872-7423. E-MAIL journals_marketing@cup.org

WEB http://www.cambridge.org

Japanese prices for individuals and institutions are available from: Kinokuniya Book Store, 5-24-2 Sendagaya, Shibuya-ku, Tokyo 151-0051, Japan TEL (o3) 5361-3301

Subscription rates are valid until 31/12/2011. Prices include delivery by air where appropriate.

Periodicals postage paid at New York, NY, and at additional mailing offices. Postmaster: send address changes in the USA, Canada, and Mexico to the Japanese Journal of Political Science, Cambridge University Press, 100 Brook Hill Drive, West Nyack, New York 10994-2133.

Claims for missing issues will be considered only if made immediately upon receipt of the subsequent issue.

This journal issue has been printed on FSC-certified paper and cover board. FSC is an independent, non-governmental, not-for-profit organization established to promote the responsible management of the world's forests. Please see www.fsc.org for information.

(c) Cambridge University Press 2012. 